\title{
The influence of dietary fatty acids on their metabolism in liver and subcutaneous fat in growing pigs*
}

\author{
G. Skiba ${ }^{1}$, E. Poławska, S. Raj, D. Weremko, M. Czauderna \\ and M. Wojtasik
}

${ }^{1}$ The Kielanowski Institute of Animal Physiology and Nutrition, Polish Academy of Sciences 05-110 Jabtonna, Poland

(Received 27 June 2011; revised version 15 July 2011; accepted 9 August 2011)

\begin{abstract}
The aim of the study was to determine the influence of fatty acids sources on their metabolism in the liver and subcutaneous fat. Four iso-energetic and iso-protein diets with different ratio of PUFA/SFA and C 18:2 n-6/C 18:3 n-3 obtained by changing part of the diet energy with plant oils (linseed or rapeseed), tallow or fish oil, were given to pigs from 60 to $105 \mathrm{~kg}$ body weight (BW). Pigs were slaughtered at $105 \mathrm{~kg} \mathrm{BW}$. The content of fatty acids in the liver and subcutaneous fat per $100 \mathrm{~g}$ tissue and the activity (index) of $\Delta 4$ - and $\Delta 9$-desaturase and elongase were determined. It was assumed that replacing part of energy of the diet with energy from different fatty acids of dietary oils will differ activity of enzymes in the investigated tissues and allow to determine in which the metabolism is more intense. Replacement of the part of the energy diets with energy from saturated (SFA), monounsaturated (MUFA) and polyunsaturated fatty acids (PUFA), improved those feeds in the quantity/quality of these fatty acids and increased their proportional content, however, more in the subcutaneous fat than in the liver. Kind of diet had no influence on weight and fat content of the investigated tissues. Irrespective of the applied diet, a lower activity of $\Delta 9$-desaturase but higher activity of $\Delta 4$-desaturase and index of elongation were detected in the liver rather than in the subcutaneous fat. Results showed that they yield of elongation of the carbon chain of fatty acids and transformation of long-chain fatty acids is higher in the liver, however stronger transformations of SFA and MUFA take place in the subcutaneous fat.
\end{abstract}

KEY WORDS: pigs, fatty acids, metabolism, liver, subcutaneous fat

\footnotetext{
*Supported by the State Committee for Scientific Research, Grant No. 2 PO6Z 00430

${ }^{1}$ Corresponding author: e-mail: g.skiba@ifzz.pan.pl
} 


\section{INTRODUCTION}

Fatty acid (FA) content in the carcass is influenced by their intake with diet and synthesis and metabolism in animals tissues and organs. The highest lipogenic activity (de novo synthesis) in pig body/carcass was observed in fatty tissue, especially in subcutaneous fat where approximately $60 \%$ of total body fat is synthesized (Mourot et al., 1995; Kuhn et al., 1997; Bergen and Mersmann, 2005). On the other hand, the liver is the organ where oxidation, elongation and desaturation of fatty acids have place. Diet supplementation with fat is commonly used in pig nutrition. This causes changes in lipogenic activity of tissues/organs (Bee et al., 2002) and results in higher fatness of carcass or muscles (Gläser et al., 2002; Pascual et al., 2007).

It was assumed that replacement of part of energy diet with energy from different fatty acids sources of oils allows to avoid an increase in carcass/muscle fatness. Thus, only activity of enzymes connected with SFA, MUFA and PUFA metabolism should be differ. The rate of this difference will depend mainly on the kind of tissue.

The aim of the study was to determine the influence of different fatty acids sources (linseed oil - PUFA n-6 and n-3, repeseed oil - MUFA, tallow - SFA and fish oil - PUFA n-3) on content of single FA and activity of the selected enzymes ( $\Delta 9$ - and $\Delta 4$-desaturases, and elongese) in liver and subcutaneous fat, as main sites of synthesis and metabolism of fatty acids. Moreover, we tried to find out in which of the analysed tissue synthesis and metabolism of fatty acids proceed with greater intensity. The obtained results may correct the values of nutritive requirements for pigs and improve the quality and health-promoting properties of pork.

\section{MATERIAL AND METHODS}

\section{Animals}

The experiment was carried out on 24 crossbred gilts ( ${ }^{\lambda}$ Danish Landrace $\mathrm{x}$ qLarge White) from 60 to $105 \mathrm{~kg}$ body weight (BW), which was accepted by the Local Ethical Commission. Origin of piglets minimized genetic variability as they were the offspring of one Danish Landrace boar and five half-sibling Large White sows. One piglet from each litter was allocated to each experimental group. Pigs were kept in individual pens $\left(2.6 \mathrm{~m}^{2}\right)$ on concrete floor, without straw, with free access to drinking water, in thermo-neutral air temperature of $18-20^{\circ} \mathrm{C}$ and humidity of $60-70 \%$. All animals were free of RYR1 and RN genes. The animals were allocated to four groups of 6 animals each and fed restrictively (85\% of 
ad libitum intake) twice a day, at 8.00 and $14.00 \mathrm{~h}$. Feed allowance was changed weekly regarding pig BW.

\section{Feeding}

Experimental diets were composed of the same component, \%: barley, 32.5; wheat, 36.0; soyabean meal, 4.0; rapeseed meal, 8.0 ; wheat bran, 12.0 and vitaminmineral mixture, 2.5; but different sources of fatty acids: diet L - 5.0\% linseed oil polyunsaturated (PUFA) n-6 and n-3, diet R - 5.0\% rapeseed oil - monounsaturated (MUFA), diet T - 5.0\% tallow - saturated fatty acids (SFA) and diet F - 5.0\% fish oil - PUFA n-3. All diets were iso-energetic and iso-protein and were balanced taking into consideration the content of ileal digestible amino acids (Table 1).

Table 1. Nutritional value, energy content and fatty acids profile, $\mathrm{g} / 100 \mathrm{~g}$ total FA, of diets

\begin{tabular}{|c|c|c|c|c|}
\hline \multirow{2}{*}{ Item } & \multicolumn{4}{|c|}{ Diet/mixture $^{1}$} \\
\hline & $\mathrm{L}$ & $\mathrm{R}$ & $\mathrm{T}$ & $\mathrm{F}$ \\
\hline Digestible protein $^{2}, \mathrm{~g} / \mathrm{kg}$ & 135 & 136 & 138 & 134 \\
\hline Lysine $^{3}$ & 8.19 & 8.23 & 8.20 & 8.23 \\
\hline Metabolizable energy, $\mathrm{MJ} / \mathrm{kg}$ & 13.58 & 13.56 & 13.58 & 13.60 \\
\hline Lys:ME & 0.60 & 0.61 & 0.60 & 0.61 \\
\hline SFA & 17.01 & 11.92 & 43.33 & 19.59 \\
\hline 14:0 & 0.21 & 0.14 & 2.02 & 2.64 \\
\hline $16: 0$ & 11.47 & 9.17 & 24.88 & 13.94 \\
\hline 18:0 & 4.84 & 2.21 & 15.13 & 2.16 \\
\hline MUFA & 22.00 & 49.46 & 30.64 & 31.43 \\
\hline $16: 1 \mathrm{n}-7$ & 0.25 & 0.27 & 1.99 & 4.06 \\
\hline $18: 1 \mathrm{n}-9$ & 20.35 & 45.94 & 26.81 & 16.99 \\
\hline $18: 1 \mathrm{n}-7$ & 1.07 & 2.65 & 1.11 & 3.01 \\
\hline $20: 1$ & 0.27 & 0.54 & 0.26 & 0.17 \\
\hline PUFA & 58.69 & 37.00 & 22.86 & 40.69 \\
\hline $18: 2 \mathrm{n}-6$ & 27.70 & 28.39 & 19.60 & 19.61 \\
\hline $18: 3 n-3$ & 30.53 & 7.55 & 3.06 & 8.88 \\
\hline $20: 4 n-6$ & 0.29 & 0.34 & 0.15 & 0.24 \\
\hline $20: 5 n-3$ & nd & nd & nd & 4.52 \\
\hline $22: 2 \mathrm{n}-11$ & 0.11 & 0.05 & 0.03 & 0.02 \\
\hline $22: 5 n-3$ & 0.03 & 0.02 & 0.01 & 0.64 \\
\hline $22: 6 n-3$ & 0.01 & 0.55 & nd & 6.54 \\
\hline PUFA/SFA & 3.45 & 3.10 & 0.53 & 2.08 \\
\hline $18: 2 n-6 / 18: 3 n-3$ & 0.91 & 3.76 & 6.41 & 2.21 \\
\hline
\end{tabular}

${ }^{1} \mathrm{~L}$ - linseed oil; R - rapeseed oil; T - tallow; F - fish oil; ${ }^{2}$ apparent digestible; ${ }^{3}$ ileal digestible; nd - not detected; content below $0.01 \mathrm{~g} / 100 \mathrm{~g}$ total FA 
Mineral mixture provided diets with the required amount of minerals, essential amino acids and vitamins (CVB, 1995). The apparent digestibility of energy and nutrients was determined after three-day faeces collection in all pigs weighing about $80 \mathrm{~kg}$, with chromium oxide as a marker. Metabolizable energy of diets was calculated based on digestible nutrient components, taking into account correction for the content of digestible protein, fat, starch and simple sugars of the organic matter (Jentsch et al., 2003).

\section{Measurements}

After slaughter at $105 \mathrm{~kg} \mathrm{BW}$, the liver was separated after about $30 \mathrm{~min}$, weighted and samples for analysis were taken. Before dissection carcasses were chilled for $24 \mathrm{~h}$ at $4^{\circ} \mathrm{C}$. Separated subcutaneous fat was weighted, grounded and homogenized, and then samples for analysis were taken.

In the collected samples chemical composition of diet content and fatty acids were determined (AOAC, 1995). The fatty acids were measured in homogenized samples with methyl esters method (Folch et al., 1957). Fatty acids methyl esters were separated by gas chromatography on GC-2010 AF Schimadzu Gas Chromatograph, equipped with a $60 \mathrm{~m}$ x $0.25 \mathrm{~mm}$ (BPX70) capillary column with helium as a carrier gas, split ratio $1: 100$, injector temperature $260^{\circ} \mathrm{C}$, detector temperature $260^{\circ} \mathrm{C}$, initial column temperature $140^{\circ} \mathrm{C}$ was maintained for $1 \mathrm{~min}$, then increased to $200^{\circ} \mathrm{C}$ at a rate $4^{\circ} \mathrm{C} / \mathrm{min}$, then increased to $220^{\circ} \mathrm{C}$ at a rate $1{ }^{\circ} \mathrm{C} / \mathrm{min}$. Total run time was $36 \mathrm{~min}$. Individual fatty acid peaks were identified in comparison with commercial standard Supelco 37 Component FAME Mix.

Metabolism of fatty acids was measured as the activity of $\Delta 9$-desaturase, $\Delta 4$-desaturase and elongase enzymes based on the ratio of the product (g) and its precursor $(\mathrm{g})$. The following formulas were used:

$$
\begin{aligned}
& \text { for } \Delta 9 \text {-desaturase }=\mathrm{C} 18: 1 \mathrm{n}-9 /(\mathrm{C} 18: 0+\mathrm{C} 18: 1 \mathrm{n}-9) \\
& \text { for } \Delta 4 \text {-desaturase }=C \text { 22:6 n-3/(C 22:5 n-3 + C 22:6n-3) } \\
& \text { for elongase } \quad=\mathrm{C} 18: 0 /(\mathrm{C} 16: 0+\mathrm{C} 18: 0)
\end{aligned}
$$

\section{Statistical analysis}

Statistical analysis were performed using one-way ANOVA of Statgraphics Centurion Professional (version XV-2005) software. Differences between treatment groups were tested using the Tukey test. 


\section{RESULTS}

There were no differences between treatment groups in weight of the liver (average $1.72 \pm 0.13 \mathrm{~kg}$ ) and subcutaneous fat tissues (average $9.89 \pm 0.64 \mathrm{~kg}$ ). Similarly fat content did not differ between the groups, on average, amounted $2.14 \pm 0.06 \%$ for liver and $78.07 \pm 1.11 \%$ for subcutaneous fat. In $\mathrm{T}$ and $\mathrm{F}$ groups concentration of SFA was higher compared with $\mathrm{L}$ and $\mathrm{R}$ groups (on average 23.5 vs $26.9 \mathrm{~g} / 100 \mathrm{~g}$ tissue, respectively; $\mathrm{P}<0.01$; Table 2). MUFA content in pigs fed the diets $\mathrm{R}$ and $\mathrm{T}$ was similar (average $32.81 \mathrm{~g} / 100 \mathrm{~g}$ tissue) but higher than in pigs of the $\mathrm{F}(30.35 \mathrm{~g} / 100 \mathrm{~g}$ tissue $)$ and $\mathrm{L}$ diets $(26.8 \mathrm{~g} / 100 \mathrm{~g}$ tissue; $\mathrm{P}<0.01)$. PUFA content was the highest in pigs fed diet L, lower in pigs fed diet $\mathrm{F}$ and $\mathrm{R}$ and the lowest in pigs fed diet $\mathrm{T}(18.91$ vs $14.29,13.43$ and $8.82 \mathrm{~g} / 100 \mathrm{~g}$ tissue; $\mathrm{P}<0.01$ ). The PUFA/SFA ratio in pigs fed diet $\mathrm{R}$ and $\mathrm{F}$ was similar (average 0.55 ) but higher $(\mathrm{P}<0.01)$ than in pigs of the $\mathrm{T}$ group $(0.33)$ and lower $(\mathrm{P}<0.01)$ than $\mathrm{L}$ group (0.82). The ratio of 18:2 n-6/18:3 n-3 was the highest $(\mathrm{P}<0.01)$ in pigs fed $\operatorname{diet} \mathrm{T}$ (5.42), lower $(\mathrm{P}<0.01)$ in animals of the $\mathrm{R} \operatorname{diet}(3.93)$ and the $\mathrm{F}$ group (3.10) and the lowest $(\mathrm{P}<0.01)$ in pigs fed $\operatorname{diet} \mathrm{L}(1.10)$.

Table 2. Fatty acids content (g FA/100 g tissue) and $\Delta$ 9-desaturase, $\Delta 4$-desaturase and index of elongation activity in subcutaneous fat of pigs slaughtered at $105 \mathrm{~kg}$ body weight

\begin{tabular}{|c|c|c|c|c|c|c|}
\hline \multirow{2}{*}{ Item } & \multicolumn{4}{|c|}{ Group $^{1}$} & \multirow{2}{*}{ Mean } & \multirow{2}{*}{ SE } \\
\hline & $\mathrm{L}$ & $\mathrm{R}$ & $\mathrm{T}$ & $\mathrm{F}$ & & \\
\hline Weight of tissue, $\mathrm{kg}$ & 9.47 & 9.68 & 9.76 & 10.83 & 9.89 & 0.644 \\
\hline Fat content, $\%$ & 77.0 & 78.2 & 76.6 & 81.1 & 78.07 & 1.109 \\
\hline SFA & $23.36^{\mathrm{A}}$ & $23.58^{\mathrm{A}}$ & $26.84^{\mathrm{B}}$ & $27.0^{\mathrm{B}}$ & 25.11 & 0.581 \\
\hline $14: 0$ & $0.70^{\mathrm{A}}$ & $0.75^{\mathrm{A}}$ & $0.86^{\mathrm{B}}$ & $0.99^{\mathrm{C}}$ & 0.82 & 0.018 \\
\hline $16: 0$ & $13.78^{\mathrm{A}}$ & $14.36^{\mathrm{A}}$ & $16.00^{\mathrm{B}}$ & $16.27^{\mathrm{B}}$ & 15.05 & 0.301 \\
\hline $18: 0$ & $8.32^{\mathrm{ab}}$ & $7.86^{\mathrm{a}}$ & $9.32^{\mathrm{b}}$ & $9.09^{b}$ & 8.63 & 0.340 \\
\hline MUFA & $26.80^{\mathrm{A}}$ & $33.15^{\mathrm{C}}$ & $32.47^{\mathrm{C}}$ & $30.35^{\mathrm{B}}$ & 30.69 & 0.554 \\
\hline $16: 1 n-7$ & $1.13^{\mathrm{C}}$ & $1.26^{\mathrm{C}}$ & $1.59^{\mathrm{A}}$ & $1.89^{\mathrm{B}}$ & 1.45 & 0.044 \\
\hline $18: 1 n-9$ & $24.02^{\mathrm{A}}$ & $29.78^{\mathrm{C}}$ & $28.65^{\mathrm{C}}$ & $25.88^{\mathrm{B}}$ & 27.13 & 0.522 \\
\hline $18: 1 n-7$ & $1.37^{\mathrm{A}}$ & $1.79^{\mathrm{B}}$ & $1.77^{\mathrm{B}}$ & $2.26^{\mathrm{C}}$ & 1.78 & 0.037 \\
\hline PUFA & $18.91^{\mathrm{C}}$ & $13.43^{\mathrm{B}}$ & $8.82^{\mathrm{A}}$ & $14.29^{\mathrm{B}}$ & 13.85 & 0.282 \\
\hline $18: 2 n-6$ & $9.04^{\mathrm{B}}$ & $9.91^{\mathrm{C}}$ & $6.85^{\mathrm{A}}$ & $8.53^{\mathrm{B}}$ & 8.58 & 0.174 \\
\hline $18: 3 n-3$ & $8.20^{\mathrm{C}}$ & $2.53^{\mathrm{B}}$ & $1.27^{\mathrm{A}}$ & $2.76^{\mathrm{B}}$ & 3.73 & 0.092 \\
\hline $20: 2 n-9$ & $0.37^{\mathrm{a}}$ & $0.45^{\mathrm{b}}$ & $0.35^{\mathrm{a}}$ & $0.38^{\mathrm{a}}$ & 0.39 & 0.023 \\
\hline $20: 4 n-6$ & $1.02^{\mathrm{A}}$ & $0.38^{\mathrm{C}}$ & $0.27^{\mathrm{B}}$ & $0.30^{\mathrm{B}}$ & 0.50 & 0.018 \\
\hline $20: 5 n-3$ (EPA) & $0.08^{\mathrm{B}}$ & $0.02^{\mathrm{A}}$ & $0.001^{\mathrm{A}}$ & $0.55^{\mathrm{C}}$ & 0.15 & 0.009 \\
\hline $22: 5 n-3$ (DPA) & $0.17^{\mathrm{C}}$ & $0.11^{\mathrm{B}}$ & $0.06^{\mathrm{A}}$ & $0.61^{\mathrm{D}}$ & 0.22 & 0.017 \\
\hline 22:6n-3 (DHA) & $0.03^{\mathrm{A}}$ & $0.03^{\mathrm{A}}$ & $0.03^{\mathrm{A}}$ & $1.18^{\mathrm{B}}$ & 0.28 & 0.018 \\
\hline PUFA/SFA & $0.82^{\mathrm{C}}$ & $0.57^{\mathrm{B}}$ & $0.33^{\mathrm{A}}$ & $0.53^{\mathrm{B}}$ & 0.52 & 0.021 \\
\hline C18:2n-6/C18:3n-3 & $1.10^{\mathrm{A}}$ & $3.93^{\mathrm{C}}$ & $5.42^{\mathrm{D}}$ & $3.10^{\mathrm{B}}$ & 3.40 & 0.130 \\
\hline$\Delta 9$-desaturase & $0.74^{\mathrm{a}}$ & $0.79^{\mathrm{b}}$ & $0.75^{\mathrm{a}}$ & $0.74^{\mathrm{a}}$ & 0.75 & 0.018 \\
\hline$\Delta 4$-desaturase & $0.15^{\mathrm{A}}$ & $0.21^{\mathrm{B}}$ & $0.33^{\mathrm{C}}$ & $0.66^{\mathrm{D}}$ & 0.34 & 0.019 \\
\hline Index of elongation & 0.38 & 0.35 & 0.37 & 0.36 & 0.36 & 0.021 \\
\hline
\end{tabular}

${ }^{1} \mathrm{~L}$ - linseed oil; R - rapeseed oil; $\mathrm{T}$ - tallow; $\mathrm{F}$ - fish oil; values in the rows with different letters differ significantly: a,b,c $-\mathrm{P}<0.05$; ${ }^{\mathrm{A}, \mathrm{B}, \mathrm{C}, \mathrm{D}}-\mathrm{P}<0.01$ 
Index of elongation did not differ between treatments (average value $=0.36$ ). Activity of $\Delta 9$-desaturase varied $(\mathrm{P}<0.05)$ between diets/groups and ranged from 0.75 (average for groups L, T, F) to 0.79 (group R). Activity of $\Delta 4$-desaturase in pigs of the group $\mathrm{F}$ was respectively four, three and two times higher $(\mathrm{P}<0.01)$ than in L, R and T groups, respectively.

SFA content in liver did not differ between the groups (average $0.86 \mathrm{~g} / 100 \mathrm{~g}$ tissue; Table 3). MUFA content was the highest in pigs fed diet $\mathrm{T}$, lower in $\mathrm{R}$ and $\mathrm{F}$ and the lowest in $\mathrm{L}$ group $(0.33,0.27,0.23$ and $0.17 \mathrm{~g} / 100 \mathrm{~g}$ tissue, respectively; $\mathrm{P}<0.01$ ). PUFA content did not differ between treatment groups (average 0.79 $\mathrm{g} / 100 \mathrm{~g}$ tissue). The PUFA/SFA ratio was higher in pigs of groups $\mathrm{L}, \mathrm{R}$ and $\mathrm{F}$ than in the group $\mathrm{T}$ (average 0.95 vs $0.83 \mathrm{~g} / 100 \mathrm{~g}$ tissue; $\mathrm{P}<0.01$ ). The ratio of $18: 2$ $\mathrm{n}-6 / 18: 3 \mathrm{n}-3$ varied $(\mathrm{P}<0.01$ ) from 4.25 (group L) to 32.0 (group $\mathrm{T}$ ).

Index of elongation was similar in pigs of groups $\mathrm{T}$ and $\mathrm{F}$ (on average 0.67 ) but lower $(\mathrm{P}<0.01)$ than in $\mathrm{R}$ and $\mathrm{L}$ groups (on average 0.74$)$. Activity of $\Delta 9$-desaturase differed $(\mathrm{P}<0.05)$ between diets/group and it was lower $(\mathrm{P}<0.01)$ in pigs of the groups $\mathrm{L}$ and $\mathrm{F}$ (average 0.23 ) compared to $\mathrm{R}$ and $\mathrm{T}$ pigs (on average 0.31 ). Activity

Table 3. Fatty acids content (g FA/100 g tissue) and $\Delta 9$-desaturase, $\Delta 4$-desaturase and index of elongation activity in liver fat of pigs slaughtered at $105 \mathrm{~kg}$ body weight

\begin{tabular}{|c|c|c|c|c|c|c|}
\hline \multirow{2}{*}{ Item } & \multicolumn{4}{|c|}{ Groups $^{1}$} & \multirow{2}{*}{ Mean } & \multirow{2}{*}{ SE } \\
\hline & $\mathrm{L}$ & $\mathrm{R}$ & $\mathrm{T}$ & F & & \\
\hline Weight of tissue, $\mathrm{kg}$ & 1.78 & 1.76 & 1.67 & 1.66 & 1.72 & 0.131 \\
\hline Fat content, $\%$ & 2.03 & 2.13 & 2.38 & 2.03 & 2.14 & 0.056 \\
\hline SFA & 0.81 & 0.83 & 0.96 & 0.81 & 0.86 & 0.051 \\
\hline $14: 0$ & 0.003 & 0.003 & 0.004 & 0.005 & 0.01 & 0.001 \\
\hline $16: 0$ & $0.17^{\mathrm{A}}$ & $0.21^{\mathrm{AB}}$ & $0.28^{\mathrm{C}}$ & $0.25^{\mathrm{BC}}$ & 0.23 & 0.017 \\
\hline 18:0 & 0.55 & 0.53 & 0.57 & 0.51 & 0.54 & 0.033 \\
\hline MUFA & $0.17^{\mathrm{A}}$ & $0.27^{\mathrm{B}}$ & $0.33^{\mathrm{C}}$ & $0.23^{\mathrm{B}}$ & 0.25 & 0.021 \\
\hline $16: 1 \mathrm{n}-7$ & $0.01^{\mathrm{A}}$ & $0.01^{\mathrm{A}}$ & $0.02^{\mathrm{B}}$ & $0.02^{\mathrm{B}}$ & 0.013 & 0.002 \\
\hline $18: 1 \mathrm{n}-9$ & $0.15^{\mathrm{A}}$ & $0.22^{\mathrm{B}}$ & $0.28^{\mathrm{B}}$ & $0.17^{\mathrm{A}}$ & 0.20 & 0.017 \\
\hline $18: 1 \mathrm{n}-7$ & $0.02^{\mathrm{A}}$ & $0.03^{\mathrm{B}}$ & $0.03^{\mathrm{B}}$ & $0.03^{\mathrm{B}}$ & 0.03 & 0.002 \\
\hline PUFA & 0.80 & 0.78 & 0.81 & 0.76 & 0.79 & 0.048 \\
\hline $18: 2 n-6$ & $0.34^{\mathrm{B}}$ & $0.31^{\mathrm{B}}$ & $0.32^{\mathrm{B}}$ & $0.21^{\mathrm{A}}$ & 0.30 & 0.020 \\
\hline $18: 3 n-3$ & $0.08^{\mathrm{B}}$ & $0.02^{\mathrm{A}}$ & $0.01^{\mathrm{A}}$ & $0.02^{\mathrm{A}}$ & 0.03 & 0.005 \\
\hline $20: 2 n-9$ & $0.007^{\mathrm{B}}$ & $0.008^{\mathrm{B}}$ & $0.007^{\mathrm{B}}$ & $0.005^{\mathrm{A}}$ & 0.01 & 0.001 \\
\hline $20: 4 n-6$ & $0.16^{\mathrm{B}}$ & $0.31^{\mathrm{C}}$ & $0.36^{\mathrm{D}}$ & $0.11^{\mathrm{A}}$ & 0.24 & 0.017 \\
\hline $20: 5$ n-3 (EPA) & $0.14^{\mathrm{C}}$ & $0.04^{\mathrm{B}}$ & $0.01^{\mathrm{A}}$ & $0.20^{\mathrm{D}}$ & 0.10 & 0.009 \\
\hline 22:5 n-3 (DPA) & 0.06 & 0.06 & 0.05 & 0.05 & 0.06 & 0.003 \\
\hline 22:6 n-3 (DHA) & $0.01^{\mathrm{A}}$ & $0.03^{\mathrm{AB}}$ & $0.04^{\mathrm{B}}$ & $0.15^{\mathrm{C}}$ & 0.06 & 0.007 \\
\hline PUFA/SFA & $0.98^{\mathrm{B}}$ & $0.94^{\mathrm{B}}$ & $0.83^{\mathrm{A}}$ & $0.93^{\mathrm{B}}$ & 0.92 & 0.018 \\
\hline $18: 2 n-6 / 18: 3 n-3$ & $4.25^{\mathrm{A}}$ & $15.50^{\mathrm{B}}$ & $32.00^{\mathrm{C}}$ & $10.50^{\mathrm{A}}$ & 14.20 & 1.737 \\
\hline$\Delta 9$-desaturase & $0.21^{\mathrm{A}}$ & $0.29^{\mathrm{B}}$ & $0.33^{\mathrm{B}}$ & $0.25^{\mathrm{A}}$ & 0.27 & 0.018 \\
\hline$\Delta 4$-desaturase & $0.14^{\mathrm{A}}$ & $0.33^{\mathrm{B}}$ & $0.44^{\mathrm{C}}$ & $0.75^{\mathrm{D}}$ & 0.42 & 0.025 \\
\hline Index of elongation & $0.76^{\mathrm{c}}$ & $0.71^{\mathrm{b}}$ & $0.67^{\mathrm{a}}$ & $0.67^{\mathrm{a}}$ & 0.70 & 0.021 \\
\hline
\end{tabular}

${ }^{1} \mathrm{~L}$ - linseed oil; R - rapeseed oil; $\mathrm{T}$ - tallow; $\mathrm{F}$ - fish oil; values in the rows with different letters differ significantly: ${ }^{a, b, c}-\mathrm{P}<0.05 ;{ }^{A, B, C, D}-\mathrm{P}<0.01$ 
of $\Delta 4$-desaturase was the highest in pigs from the group $\mathrm{F}$, lower in $\mathrm{T}$, $\mathrm{R}$ groups and the lowest in $\mathrm{L}$ group ( 0.75 vs $0.44,0.33$ and 0.14 , respectively; $\mathrm{P}<0.01)$.

Index of the $\Delta 9$-desaturase activity was almost three times higher in the subcutaneous than in the liver fat (on average 0.75 vs 0.27 , respectively). However in case of $\Delta 4$-desaturase this difference was lower ( 0.34 vs 0.42 , respectively for subcutaneous and liver fat). Contrary, the index of elongation was two times higher in the liver than in the subcutaneous fat (on average $0.70 \mathrm{vs} 0.36$, respectively).

\section{DISCUSSION}

Replacement of the part of the diet energy with energy from the various sources of fatty acids did not influence the weight of the liver and subcutaneous fat. Mitchaothai et al. (2007) who fed pigs iso-energetic and iso-protein diets with diverse supply of fatty acids also found no influence of experimental treatment on the weight and chemical composition of the body, carcass and liver. Similar results were found by Szabó et al. (2001), Kouba et al. (2003), Nuernberg et al. (2005), Osek and Milczarek (2005).

Replacement of the part of the energy diets with energy from SFA, MUFA and PUFA, caused improvement of those feeds in the quantity/quality of these fatty acids and increased their proportional content, which was also presented in many earlier studies (e.g., Wiseman and Agunbiade 1998; Bee et al., 2002; Gläser et al., 2002; Mitchaothai et al., 2007). However, when the changes in the $100 \mathrm{~g}$ of the tissues were considered the differences were not big particularly in the liver. Thus, the applied feeding did not influence the content of SFA and PUFA in $100 \mathrm{~g}$ of the liver. The direction of changes in content of fatty acids in $100 \mathrm{~g}$ of the subcutaneous fat was in agreement with the content of fatty acids in particular sources of fat.

Feeding pigs with the mixture in which the part of energy was replaced by energy from MUFA the activity of $\Delta 9$-desaturase increased in comparison with pigs fed diet with other sources. It was a result of the higher quantity of the product (18:1 n-9) in the diet as well its deposition in tissues/organs. Feeding pigs a diet with higher quantity of the precursor SFA also increased the activity of $\Delta 9$-desaturase. Bee et al. (2002) confirmed such a difference in backfat of pigs fed diet with tallow including approx. 33\% 18:1n-9 and approx. 18\% 18:0. Feeding the mixture in which the part of energy was replaced by energy from PUFA the activity of $\Delta 9$-desaturase did not change, as this diet did not introduce SFA and MUFA, additional amount of precursor (C18:0) and the product (18:1n-9). Bee et al. (2002) and Kouba et al. (2003) also confirmed regulating/blocking influence of feeding pigs a diet with higher amount of PUFA on the activity $\Delta 9$-desaturase. 
Moreover, Ntawubizi et al. (2009) confirmed the relationship between the activity of $\Delta 9$-desaturase and the fat content in muscles. However, it seems that changes as a result of feeding with the different supply of fatty acids, are independ from the fat content in liver and subcutaneous fat. The relationships were not supported in present studies.

However, Guillevic et al. (2009) suggest that not only PUFA content but also ratio of $n-6 / n-3$ are important, because when the content of PUFA is almost similar and PUFA n- 6 content is higher, the activity of $\Delta 4$-desaturase is also elevated. Our results confirm these findings that increased ratio of $n-6 / n-3$ in diets consequently resulted in higher ratio of n-6/n-3 in the investigated tissues and higher activity of $\Delta 4$-desaturase as well. This relationship confirmed the differences between pigs fed diet with rapeseed oil and tallow vs linseed oil. It is due to the lack of necessity for synthesis of the long chain PUFA if they are supplied with diets. On the other hand, Zhang et al. (2009) studying in vitro cells of rats did not find influence of elevated concentration of PUFA on activity of the $\Delta 4$-desaturase. Discrepancy in the results of our study and above mentioned investigations probably resulted from differences in metabolism of fatty acid in pigs and rats. Moreover, above cited authors used diet reach in PUFA but mainly from n-3 family. In our study higher activity of $\Delta 4$ - desaturase was found in pigs fed diet supplemented with tallow being source of SFA. Low content of the long chain PUFA in this diet undoubtedly stimulated their synthesis. Our results indicate the low amount of the DPA, being precursor of DHA, in the diet increased the yield of $\Delta 4$-desaturase in pigs fed diet with fish oil resulted from common action of enzyme and direct absorption of DHA from the diet and it deposition in the tissue. It is well known that abundance of DHA in fed diet resulted in its direct absorption by tissue (Wood et al. (2008).

Feeding pigs diet rich in PUFA and MUFA increased activity of elongase, however, lack of literature data concerning this issue make detailed discussion difficult.

Despite the applied feed, liver showed lower activity of the $\Delta 9$-desaturase, but higher activity of the $\Delta 4$-desaturse and elongase compared to subcutaneous fat tissue. It suggests that in subcutaneous fat process of transformation of SFA to MUFA elongation is more intense. However, the yield of the carbon chain elongation and metabolism of long chain fatty acids is higher in the liver than subcutaneous fat. Our results indicate that direction of changes in the yield of fatty acids enzyme metabolism related to both feeding system and type of tissue where the activity of enzymes takes place. 


\section{CONCLUSIONS}

Replacement of the part of energy of the diet by energy from various sources (linseed or rapeseed oil, tallow, fish oil) of fatty acids (FA) does not influence weight and fat content in liver and subcutaneous fat. Elongation of the carbon chain of FA and transformation of long-chain FA are higher in the liver, however, stronger transformations of saturated and monounsaturated fatty acids take place in the subcutaneous fat.

\section{REFERENCES}

AOAC, 1995. Association of Official Analytical Chemists, Official Methods of Analysis. $16^{\text {th }}$ Edition. Arlington, VA.

Bee G., Gebert S., Messikommer R., 2002. Effect of dietary energy supply and fat source on the fatty acid pattern of adipose and lean tissues and lipogenesis in the pig. J. Anim. Sci. 80,1564-1574

Bergen W.G., Mersmann H.J., 2005. Comparative aspects of lipid metabolism: Impact on contemporary research and use of animal models. J. Nutr. 135, 2499-2502

CVB, 1995. Table of Feedstuffs. Information about Composition, Digestibility and Feeding Value (in Dutch), No. 18, Central Veevoeder Bureau, Lelystad (The Netherlands)

Folch J., Lee M., Sloane Stanley G.H., 1957. A simple method for the isolation and purification of total lipids from animal tissues. J. Biol. Chem. 22, 226-497

Gläser K.R.., Wenk C., Scheeder M.R.L., 2002. Effect of dietary mono- and polyunsaturated fatty acids on the fatty acid composition of pigs' addipose tissues. Arch. Anim. Nutr. 56, 51-65

Guillevic M., Kouba M., Mourot J., 2009. Effect of a linseed diet or a sunflower diet on performances, fatty acid composition, lipogenic enzyme activities and stearoyl-CoA-desaturase activity in the pig. Livest. Sci. 124, 288-294

Jentsch W., Chudy A., Beyer M., 2003. Rostock Feed Evaluation System. Reference Numbers of Feed Value and Requirement on the Base of Net Energy. Research Institute for the Biology of Farm Animals, Member of the Leibniz Association, Research Unit Nutritional Physiology 'Oskar Kellner', Dummerstorf (Germany)

Kouba M., Enser M., Whittington F.M., Nute G.R., Wood J.D., 2003. Effect of a high-linolenic acid diet on lipogenic enzyme activities, fatty acid composition, and meat quality in the growing pig. J. Anim. Sci. 81, 1967-1979

Kuhn G., Hartung M., Nürnberg G., Falkenberg H., Langhammer M., Schwerin M., Ender K., 1997. Growth,carcass composition ane meat quality in pigs with different capacity for lipid deposition. Arch. Tierzucht 40, 345-355

Mitchaothai J., Yuangklang C., Wittayakun S., Vasupen K., Wongsutthavas S., Srenanul P., Hovnier R., Everts H., Beynen A.C., 2007. Effect of dietary fat type on meat quality and fatty acid composition of various tissues in growing-finishing swine. Meat Sci. 76, 95-101

Mourot J., Kouba M., Peiniau P., 1995. Comparative study of in vitro lipogenesis in various adipose tissues in the growing domestic pig (Sus domesticus). Comp. Biochem. Physiol. Pt B 111, 379384

Ntawubizi M., Raes K., Buys N., De Smet S., 2009. Effect of sire and sex on the intramuscular fatty acid profile and indices for enzyme activities in pigs. Livest. Sci. 122, 264-270 
Nuernberg K., Fischer K., Nuernberg G., Kuechenmeister U., Kłosowska D., Elminowska-Wenda G., Fiedler I., Ender K., 2005. Effects of dietary olive and linseed oil on lipid composition, meat quality, sensory characteristics and muscle structure in pigs. Meat Sci. 70, 63-74

Osek M., Milczarek A., 2005. Results of fattening, slaughter value and meat quality of Puławska pigs fed mixtures with faba bean and rapeseed (in Polish). Rocz. Nauk. Zoot. 32, 103-113

Pascual J.V., Rafecas M., Canela M.A., Boatella J., Bou R., Barroeta A.C., Codony R., 2007. Effect of increasing amounts of a linoleic-rich dietary fat on the fat composition of four pig breeds. Part II: Fatty acid composition in muscle and fat tissues. Food Chem. 100, 1639-1648

Szabó C., Jansman A.J.M., Babinszky L., Kanis E., Verstegen M.W.A., 2001. Effect of dietry protein source and lysine:DE ratio on growth performance, meat quality, and body composition of growing-finishing pigs. J. Anim. Sci. 79, 2857-2865

Wiseman J., Agunbiade J.A., 1998. The influence of changes in dietary fat and oils on fatty acid profiles of carcass fat in finishing pigs. Livest. Prod. Sci. 54, 217-227

Wood J.D., Enser M., Fisher A.V., Nute G.R., Sheard P.R., Richardson R.I., Hughes S.I., Whittington F.M., 2008. Fat deposition, fatty acid composition and meat quality: A review. Meat Sci. 78, 343-358

Zhang S., Knight T.J., Stalder K.J., Goodwin R.N., Lonergan S.M., Beitz D.C., 2007.Effects of breed,sex and helothane genotpe on fatty acid composition of pork longissimus muscle. J. Anim.Sci. 85, 583-591 